IZA DP No. 7202

Job Search as a Determinant of Graduate Over-Education: Evidence from Australia

David Carroll

Massimiliano Tani

February 2013 


\title{
Job Search as a Determinant of Graduate Over-Education: Evidence from Australia
}

\author{
David Carroll \\ Macquarie University \\ Massimiliano Tani \\ Macquarie University \\ and IZA \\ Discussion Paper No. 7202 \\ February 2013 \\ IZA \\ P.O. Box 7240 \\ 53072 Bonn \\ Germany \\ Phone: +49-228-3894-0 \\ Fax: +49-228-3894-180 \\ E-mail: iza@iza.org
}

Any opinions expressed here are those of the author(s) and not those of IZA. Research published in this series may include views on policy, but the institute itself takes no institutional policy positions. The IZA research network is committed to the IZA Guiding Principles of Research Integrity.

The Institute for the Study of Labor (IZA) in Bonn is a local and virtual international research center and a place of communication between science, politics and business. IZA is an independent nonprofit organization supported by Deutsche Post Foundation. The center is associated with the University of Bonn and offers a stimulating research environment through its international network, workshops and conferences, data service, project support, research visits and doctoral program. IZA engages in (i) original and internationally competitive research in all fields of labor economics, (ii) development of policy concepts, and (iii) dissemination of research results and concepts to the interested public.

IZA Discussion Papers often represent preliminary work and are circulated to encourage discussion. Citation of such a paper should account for its provisional character. A revised version may be available directly from the author. 
IZA Discussion Paper No. 7202

February 2013

\section{ABSTRACT \\ Job Search as a Determinant of Graduate Over-Education: Evidence from Australia}

This study considers the relationship between job search and over-education amongst recent Australian bachelor degree graduates. Using a panel estimation method, we find that using universities' career offices is associated with a reduced probability of over-education (between 3\% and 8\%) vis-à-vis responding to a job advertisement or searching through networking. These results are robust to alternative specifications and estimation techniques. As over-education is characterised by high persistence, the role of university career services and fairs in screening and matching the skills of graduands with the needs of employers at the entry point into the labour market cannot be overlooked.

JEL Classification: $\quad$ A22, I23, J24

Keywords: $\quad$ over-education, graduate labour market, job search

Corresponding author:

Massimiliano Tani

Department of Economics

Macquarie University

NSW 2109

Australia

E-mail:max.tani@mq.edu.au 


\section{Introduction}

It is well documented that a substantial proportion of Australian university graduates possess more education than is strictly required for them to perform their jobs, at both entry point into the labour market (e.g. Carroll and Tani, 2013) as well as later on in their working lives (e.g. Kler, 2005; Mavromaras, McGuinness, O’Leary, Sloane and Wei, 2010) ${ }^{1}$, in line with international trends (e.g. Duncan \& Hoffman, 1981; Hartog, 2000; Metha, Felipe, Quising \& Camingue, 2011). Over-education is a costly phenomenon, as is associated with reduced individual earnings (e.g. Alba-Ramirez, 1993; Dolton \& Vignoles, 2000), and low job satisfaction and individual productivity (e.g. Tsang \& Levin, 1985). Its typical causes are related to individual features like effort and performance (e.g. Verhaest \& Omey, 2009), age and gender, and, most importantly, the field of education (e.g. Battu, Belfield \& Sloane, 1999).

Relatively little attention has so far been given to the method by which graduates find work. In particular, though many empirical studies have shown that job search methods can influence employment outcomes such as earnings, work duration and job satisfaction (e.g. Addison \& Portugal, 2002; Krug \& Rebien, 2011; Weber \& Mahringer, 2006), few have analysed in detail the link between job search and over-education (e.g. Franzen \& Hangartner, 2006; Blázquez \& Mora, 2010; Kucel \& Byrne, 2008). Yet, it is unlikely that different job search methods provide the same probability of over-education: some may emerge as more or less efficient, on average, in leading to a job where the under-use of competences acquired during graduate studies is minimised.

In this paper we provide evidence of the relationship between over-education and job search methods in Australia using a unique database, the 2011 Beyond Graduation Survey (BGS), which records the labour market activities of a cohort of recent Australian graduates in 2008 and 2011. Five search methods are considered, namely university-based job search, job advertisements, contact networks, direct contact with employers, and 'other methods' not listed on the survey. Thanks to the

\footnotetext{
${ }^{1}$ We refer to "over-education" to locate our work within a well-established literature. However, we believe that over-education can arguably be more rightly thought of as "under-utilisation”. Being employed below their level of education does not necessarily mean that a graduate possesses more education than society would consider to be optimal, but his/her productive capacity as a highly skilled worker is almost certainly under-utilised.
} 
panel nature of the data we are able to control for individual unobserved heterogeneity and limit this source of potential bias.

Our results show that finding a job using a university-based search method is associated with a 3\%-8\% reduced probability of over-education compared with responding to a job advertisement. The estimated effect arises for both ‘traditional' (up to 25 years of age) and non-traditional graduates (age 25+) of both genders, though older male graduates who found their jobs through their network were also less likely to be over-educated.

Our findings have relevant implications for both theory and higher education policy, as it provides new insights into the causes of over-education at the starting point of a graduate's working life as well as support to university career services as effective offices matching graduands' skills with employers' demand. The rest of the paper is organised as follows. Section 2 presents a brief literature review and outlines our contribution. Section 3 describes the data and variables used in our analysis. Section 4 describes the model and estimation strategy. Section 5 presents the results. Conclusions and implications are presented in Section 6. Variable definitions are given in Appendix A.

\section{Literature}

A broad international literature has shown that a substantial proportion of graduates work jobs that do not notionally require a university degree (see Kucel, 2011 for a survey). With specific regard to the Australian labour market, Kler (2005) reports that, depending on the measure used, the incidence of over-education amongst tertiary educated workers was between $21 \%$ and $46 \%$ for males, and between 21\% and 38\% for females at the time of the 1996 Australian census. Mavromaras et al. (2010), using data from the 2001-07 waves of the Household Income and Labour Dynamics in Australia (HILDA) survey, report that $20 \%$ of males and $17 \%$ of females in their sample of tertiary educated workers were over-educated. Carroll and Tani (2013), using panel data from the 2010 BGS, found that between $24 \%$ and $37 \%$ of bachelor degree graduates were over-educated shortly after course completion, though that the over-education rate decreased to between $12 \%$ and $21 \%$ within three years. 
Over-education rates vary considerably across fields of study, with lower rates for "professional” fields of engineering, mathematics, sciences, law and medicine (Battu, Belfield and Sloane, 1999) and other “prestigious” fields (McGuinness and Sloane, 2011). Conversely higher rates of over-education affect graduates working during their final year of study, as well we those in parttime employment and those with low average grades (e.g. Dolton and Silles, 2001). Major field of study and final grade achieved emerge as consistent determinants of over-education (Verhaest and Omey, 2010), along with general economic conditions as proxied by the unemployment rate (Gottschalk and Hansen, 2003; Cardoso, 2007; Grazier, O’Leary \& Sloane, 2008).

Three studies have investigated the relationship between job search and graduate overeducation in some detail. Franzen and Hangartner (2006), using cross-sectional data from the 2001 Swiss Graduate Survey conducted one year after graduation ${ }^{2}$, find that graduates who obtained their jobs through social networks, active job search and direct employer applications had a greater probability of being in a job that required an appropriate qualification relative to graduates who found their jobs through formal search channels, such as responding to job advertisements and using employment agencies. Kucel and Byrne (2008) using pooled cross-sectional data from the UK Quarterly Labour Force Survey spanning 2003-2005 to investigate whether different job search methods were associated with different probabilities of over-education ${ }^{3}$, find that responding to job advertisements, applying through a private employment agency and using some other method not listed on the survey reduced the probability of over-education compared with finding a job using personal contacts. The only search method in their study that was associated with an increased probability of over-education relative to the use of personal contacts was the state employment office. ${ }^{4}$ Blázquez and Mora (2010) using cross-sectional data from a 2001 survey of Spanish university graduates who completed their studies five years earlier to examine the role of job mobility

\footnotetext{
${ }^{2}$ Graduates were asked whether their current employment required no degree at all, a general degree, one from a related subject, or a specific degree. This was treated as an ordinal dependent variable. An ordered probit model was used to assess the association between job search and educational adequacy.

${ }^{3}$ To ensure that the assumption concerning the independence of observations was not violated, Kucel and Byrne (2008) used every fifth quarterly dataset in their analysis. This meant that a given individual would appear in the analysis sample only once.

${ }^{4}$ The relative inefficiency of the state employment office is a common finding in the job search literature (e.g. Holzer, 1988; Blau \& Robins, 1990; Osberg, 1993; Addison \& Portugal, 2002).
} 
in graduate over-education, find that graduates who found their jobs though a university careers office were the least likely to be over-educated, whereas those graduates who found their jobs through a public service examination were the most likely to be over-educated. They attributed this latter finding to graduates seeking out public service positions as a way to achieve job security, even though the roles may be below their level of education.

A common limitation of these existing studies is that none control for unobserved differences across individuals that may be correlated with usage of different job search methods, such as ability or motivation. An individual who invests time and effort in using a university careers office to find a job, for example, may also be a more conscientious student than an individual who chooses a less "costly" search method to find work, and it is this unobserved characteristic that influences their probability of being over-educated in the graduate labour market. This limits the ability of these previous studies to draw inferences regarding the link between job search and over-education. This limitation can be however reduced if panel data are available ${ }^{5}$, as carried out in our study. Moreover, as we split the sample into four gender-age cohorts, representing traditional school-leavers (i.e. aged less than 25 years at the time of graduation) and the non-traditional mature-age cohort (which accounts for $20 \%$ of undergraduate enrolments in Australia - Department of Industry, Innovation, Science, Research and Tertiary Education [DIISRTE], 2012), we analyse whether different levels of work experience affect the relative effectiveness of various job search methods.

\section{Data}

The empirical analysis is carried out on data from the 2011 Beyond Graduation Survey. Since 1972, graduates from Australian higher education institutions have participated in a representative national survey on their labour market outcomes and further study activities approximately four months after completing their studies. ${ }^{6}$ The current incarnation of this survey is the Australian

\footnotetext{
${ }^{5}$ Though ability and motivation are also time dependent, they are likely to vary more across individuals than across time for each individuals. Hence eliminating an individual's 'average' ability and motivation is (hopefully) controlling for a substantial portion of this unobserved variable.

${ }^{6}$ Although the AGS is administered as a national graduate census, the non-response rate for Australian domestic graduates is around 40\% (Graduate Careers Australia [GCA], 2012a). A study by Coates, Tilbrook, Guthrie and Bryant (2006) established that the survey is not subject to problematic non-response bias.
} 
Graduate Survey (AGS), which is conducted annually by Graduate Careers Australia (GCA). The

BGS was developed as a cohort-style follow-up to the AGS, whereby respondents were invited to

complete a survey on their work and study activities in the three years immediately after course

completion. In all, around 70\% of the institutions that participated in the 2008 AGS also participated

in the 2011 BGS, with an average survey response rate of 20\% (GCA, 2012b). ${ }^{7}$

The cohort of interest consists of bachelor degree graduates employed in Australia in each of the two survey waves. ${ }^{8}$ The sample consists of 2,687 graduates, all of them living in Australia, with two matched observations for each individual taken three years apart.

Of the three methods for measuring over-education dominate the empirical literature ${ }^{9}$ we used the JA method to construct our dependent variable. This choice was dictated by the survey data. Occupational skill levels from ANZSCO served as a basis for classification. ${ }^{10}$ The five ANZSCO skill levels were coded into a binary variable. ${ }^{11}$ Graduates in Skill Level 1 occupations, which require a bachelor degree or higher qualification, were classified as not over-educated. Those in the four lower skill levels were classified as over-educated. Clearly, this ANZSCO-based definition implicitly underestimates the extent of over-education for individuals with a postgraduate degree, hence our preference for a bachelor-only sample. Graduates’ occupations were coded on the basis of two opentext response items on each questionnaire: “what was the full title of your occupation?” and "what were the main tasks and duties in your job?”. By assigning graduates to different occupational

\footnotetext{
${ }^{7}$ The skew towards females in our sample is not unexpected due to the fact that females constitute around $60 \%$ of course completions from Australian higher education providers (DIISRTE, 2012).

${ }^{8}$ Self-employed graduates were excluded as they are not relevant to an investigation of job search methods.

${ }^{9}$ These are the Worker Self-Assessment (WA) method, the Realised Matches (RM) method, and the Job Analysis (JA) method. The WA method measures over-education by comparing the minimum education level that a worker believes is needed to perform his or her job to their actual level of education. The RM method is based on the average education level in an occupation. A worker is typically considered to be over-educated if his or her actual level of education is more than one standard deviation above the average for his or her occupation. The JA method measures over-education by means of occupational definitions developed by professional job analysts. A worker is considered to be over-educated if his or her actual education level is higher than the required education level specified in the classification scheme. Each of these methods have advantages and shortcomings, which are discussed in detail by Halaby (1994) and Hartog (2000).

${ }^{10}$ In the context of ANZSCO, a skill level is a function of both the range and complexity of tasks in a particular occupation. A greater range and complexity of tasks is associated with a higher skill level (Australian Bureau of Statistics [ABS], 2006).

${ }^{11}$ Skill Level 1 corresponds to a bachelor degree or higher qualification; Skill Level 2 to an Associate Degree, Advanced Diploma or Diploma; Skill Level 3 to an Australian Qualifications Framework (AQF) Certificate IV; Skill Level 4 to an AQF Certificate III or II; Skill Level 5 to an AQF Certificate I or completion of compulsory secondary education (ABS, 2006).
} 
categories (and, by extension, different skill levels) on the basis of their self-described tasks in addition to the title of their occupation, the main criticism associated with the JA method (the assumption that workers with the same occupation title are doing work of equal difficulty - Dolton \& Vignoles, 2000) is at least partly addressed. ${ }^{12}$

The independent variables are a set of four dummies indicating how graduates first found out about the job they held at the time of the survey. Graduates were presented with a list of 12 response options and were instructed to select one. We combined these options into five broad job search methods to prevent overly low numbers of observations. These are defined as follows: universitybased method, which consists of university careers offices and graduate careers fairs; networking, which includes searching for work through friends, relatives and work contacts; direct employer contact, which denotes job search by approaching an employer directly; and other job search method, which covers all other methods not listed on the questionnaire. The omitted category, advertisements, consists of print and online job advertisements. These variables can be thought of as a graduate's primary method of job attainment. ${ }^{13}$

As the BGS does not record the entire span of a graduate's labour market experience, we use age as a proxy for potential experience. The university quality variable is generated as the first principal component of two relevant indicators: institutional student-staff ratios and first-year attrition rates, ${ }^{14}$ both of which are moderately correlated $(r=0.341, p=0.070)$. These indicators reflect usage for university quality in previous studies (e.g. Black \& Smith, 2006), and availability across all 29 public universities in our data. The direction of this variable is such that smaller values are associated with higher-quality universities.

The means of all the variables used are given in Table 1 , stratified by gender-age cohort and their full definition is in Appendix A. Table 1 shows that young females were considerably more

\footnotetext{
${ }^{12}$ A graduate with the occupation title "Manager" with the tasks of a finance manager will, for example, be assigned a higher skill level than a similarly titled graduate with the tasks of a restaurant manager.

${ }^{13}$ Although not captured in our data, graduates could have potentially used other job search methods in addition to the main method identified on the survey. Indeed, the concurrent use of multiple job search methods has been noted by, for example, Holzer (1988), and Gregg and Wadsworth (1996).

${ }^{14}$ These indicators relate to 2007. Student-staff ratios were computed as full-time equivalent (FTE) student load divided by FTE teaching staff, based on data from the Department of Education, Employment and Workplace Relations (DEEWR) (2008a; 2008b). First-year attrition rates represent the percentage of domestic students who commenced a bachelor course in 2007 and did not complete the course nor reenrol in 2008 (DEEWR, 2009).
} 
likely to be over-educated than young males, and that young graduates were more likely to be overeducated than older graduates. In the non-traditional cohort, similar proportions of males and females were over-educated. The most noticeable differences between traditional and non-traditional graduates in terms of their usage of job search methods is that those in the former cohort were more likely to have found jobs using university-based methods, while those in the latter cohort were more likely to have found jobs through direct employer contact or some other job search method not listed on the questionnaire.

[Table 1 here]

\section{Empirical approach}

We model the probability of graduate over-education as a function of various potential determinants, including age, major field of study, university quality score, work status during their final year of study, working on a part-time or casual basis, job search method and employment location. We also include a time dummy for year 2011 to account for time-specific factors that affect all individuals in our sample, such as labour market conditions at the time of each survey wave. Our main interest lies in analysing the impact of various, mutually exclusive job search methods on the probability of over-education, conditional on these other determinants. To this end, we first estimate a conventional random-effects probit model, which can be described by the following latent variable model:

$$
y_{i t}^{*}=x_{i t} \beta+c_{i}+e_{i t}
$$

where $y_{i t}=1$ if the graduate is over-educated $\left(y_{i t}^{*}>0\right)$ and $y_{i t}=0$ otherwise. The vector $x_{i t}$ contains all of the observed determinants. Under this specification, the individual effect $c_{i}$, which captures unobserved heterogeneity, is treated as a random variable. Both $c_{i}$ and the error term $e_{i t}$ are 
assumed to be distributed independently of $x_{i t}$ and follow the normal distribution, with $c_{i} \sim N\left(0, \delta_{c}^{2}\right)$ and $e_{i t} \sim N(0,1)$. This model is estimated using the quadrature method. ${ }^{15}$

In practice, the assumption of zero correlation between $c_{i}$ and $x_{i t}$ may be unrealistic and, if it is not satisfied, the estimates may be inconsistent. We address this by using the technique proposed by Mundlak (1978) and described in Wooldridge (2002) (itself adapted from Chamberlain, $1980^{16}$ ) whereby we use the following latent variable model:

$$
y_{i t}^{*}=\psi+x_{i t} \beta+\bar{x}_{i} \xi+a_{i}+e_{i t}
$$

where $\bar{x}_{i}$ is the time average of $x_{i t}$ and $a_{i}$ is the individual effect, with $a_{i} \mid x_{i} \sim N\left(0, \delta_{a}^{2}\right)$. Adding $\bar{x}_{i}$ to the model as a control for time-invariant unobserved heterogeneity is intuitive, since it allows one to estimate the effect of changing $x_{i t j}$ whilst holding the time average fixed (Wooldridge, 2002).

Time-invariant regressors and the time dummy, which does not vary across $i$, are omitted from $\bar{x}_{i}$.

One potential limitation of this approach is that it does not account for time-variant individual heterogeneity. For example, some over-educated graduates may obtain useful work experience in their first jobs after graduation, which would influence their probability of over-education in the future but would not be captured by the model.

Another significant limitation is that this approach does not control for selection into employment. The results may therefore be affected by the presence of unobserved characteristics that affect both the likelihood of over-education and participation in the labour market, such as innate ability.

\section{Results}

Table 2 reports probit coefficients from the estimation of Eq. (1) and the average marginal effects (AMEs) for the key explanatory variables. Finding a job using university career services emerges as the search methods landing jobs with lower probability of over-education relative to finding a job through an advertisement (the base category) across all four cohorts. This finding echoes

\footnotetext{
${ }^{15}$ We used the "xtprobit" command in Stata and specified random effects.

${ }^{16}$ This is commonly referred to in the literature as the Mundlak-Chamberlain approach.
} 
that of Blázquez and Mora (2010). In addition, older male graduates are less likely to be overeducated if they found work by contacting an employer directly. The AMEs indicate that the magnitude of this effect is somewhat weaker than that for university-based job search. Older females who found their jobs through networking or direct employer contact had an increased probability of over-education relative to those who responded to job advertisements.

[Table 2 here]

The other significant effect reported in Table 2 is the reduced probability of over-education for older males who found their jobs through networking. This result suggests that many appropriate graduate jobs for older males are found in the so-called "hidden" job market and are not necessarily advertised using traditional means. The same effect was not observed for young graduates nor older females, for whom networking offered no advantage over answering job advertisements.

Other potential determinants of over-education include age (or potential work experience) and the field of education. As shown in Table 2, additional years of age have no significant effect on the over-education probability of young graduates of either gender. This is not an unexpected result, given that traditional graduates generally lack experience due to their youth. Extra years of age were associated with a higher probability of over-education for older males, while the opposite was observed for older females. This could suggest that older male graduates are less mobile in their careers, insofar as they may be more likely than females to remain in low-skilled jobs.

Consistent with earlier studies, field of study is a major determinant. For young graduates, a degree in an engineering or related field, health or education is associated with a lower probability of over-education compared with a degree in management and commerce. Young male IT graduates also saw a lower probability of education. Older males with degrees in society and culture, or creative arts were significantly more likely to be over-educated. Older female graduates with degrees in health or education were less likely to be over-educated, whereas the opposite was true for those graduates with a degree in IT. The estimates presented in Table 2 are strongly correlated with corresponding full-time unemployment rates calculated from the AGS ( $r=0.583 ; p<0.001)$, which implies that these field of 
study results reflect the relative demand for discipline-specific skills in the Australian graduate labour market. This supports an earlier descriptive analysis of Australian university graduates by Carroll and Tani (2013), and echoes the link between unemployment and over-education identified by Gottschalk and Hansen (2003), among others.

The only significant association between university quality and over-education was observed for young males. The sign on the coefficient is in the expected direction (i.e. graduating from a lowerquality university is associated with a higher probability of over-education), ${ }^{17}$ although the magnitude of the effect is quite modest. Since it is unlikely that only young males benefit from attending a highquality university, it is possible that this result is due to selectivity. Young high-ability males may, for example, be more concentrated in high-quality universities than is the case for other cohorts. ${ }^{18}$ The lack of an ability proxy in our data, along with the inability of our estimation methodology to control for the effect of unobserved heterogeneity on time-invariant regressors, means that we are unable to establish whether this particular interpretation is the correct one.

Older females who were in paid work in their final year of study had a greater probability of over-education. Because it is somewhat counterintuitive that individuals with more experience would be at a greater risk of becoming over-educated, this result may suggest that these graduates are more likely to remain in the jobs that they held during study after the completion of their degrees. It should also be noted that the vast majority of all graduates were in paid work during their final year of study, so this result may simply reflect unmeasured characteristics in these large subgroups.

Because conventional random-effects estimates might be inconsistent due to the presence of unobserved time-invariant heterogeneity, we estimate the Mundlak-Chamberlain model given in Eq. (2) and report the results in Table 3. We do not report the estimates of the time-invariant covariates in Table 3 because the addition of time-averages does not substantially change the results. It can be seen that, even after controlling for unobserved individual heterogeneity, university-based job search is still

\footnotetext{
${ }^{17}$ A similar result was obtained using different university quality measures, including a set of dummy variables for Australian university groups (e.g. Birch, Li \& Miller, 2009) and university ratings from Williams (2008).

${ }^{18}$ Some evidence in support of this proposition can be found in university admissions data (Queensland Tertiary Admissions Centre, 2012). Considering school-leavers with an Overall Position (OP) rank of 5 or better, 61\% of males enrolled in Queensland's highest-rated university, compared with 50\% of females. OP ranks range from 1 (highest) to 25 (lowest). Comparable statistics are not published by other state admissions centres.
} 
associated with a lower probability of over-education relative to finding a job by responding to a job advertisement. Notably, however, the magnitude of this effect is weaker once time-invariant heterogeneity is addressed, suggesting that at least some of this effect is attributable to the unobserved characteristics. One possible interpretation could be that graduates who use university-based job search methods tend to be more able students, or are better screened prior to applying for a job, and this accounts for their labour market success.

[Table 3 here]

At least two explanations for the effectiveness of university-based job search relative to other methods are likely. First, the distribution of jobs offered through the universities' career services might be more suitable for graduands than those offered through other channels. For example, jobs in the university-based offer distribution might be skewed towards first-job occupations relative to those available through alternative search channels. Employers seeking to recruit 'generic' workers (as opposed to new graduands') may be reluctant to go to the additional expense of using the universitybased channel, which exclusively targets individuals who are finishing their degree. Employers seeking to recruit graduands, for example for training programs, may conversely have a preference for the university-based channel for this very reason. Although we do not have any data on rejected offers, we can attempt to illustrate this proposition using occupational skill level data from the BGS, stratified by job search channel. As shown in Table 4, jobs found through university-based search methods have the highest average skill level out of any search channel and also the smallest spread of occupational skill levels, which is consistent with the idea of 'targeted' recruitment.

[Table 4 here] 
Second, given that university careers offices exist, in part, to gather and dispense information on graduate job vacancies and provide career guidance, ${ }^{19}$ it is possible that the lower skills dispersion associated with university-based search methods is caused by an informational advantage: namely, the possibility for job seekers to gather better information about the availability of appropriate jobs for their level of education and experience, as well as perhaps expressed revelation of preferences that might help university career offices to enact a better match.

In light of the evidence that university-based job search is associated with a lower probability of over-education in the graduate labour market, it is surprising that this method is not more widely used by graduate jobseekers. For example, data from the 2011 AGS show that university-based methods are used by only $47 \%$ of graduates as part of their overall job search strategy. ${ }^{20}$ By contrast, $78 \%$ reported searching for work through advertisements, $61 \%$ contacted employers directly and 52\% used their contact networks. This result suggest the potential benefit of providing incentives to graduands to make the necessary investment of time and effort to visit university career advice centres, or to 'advertise' the university career service to the graduands' community if lack of information is at the root of the relative low usage of such job search channel.

\section{Conclusions and implications}

Although graduate over-education is a common and well-documented phenomenon, which is costly for both the affected individual and the wider economy, the determinants of over-education are not well understood. The main purpose of this study was to analyse the link between job search and over-education for Australian bachelor degree graduates, using panel data from the 2011 BGS and an estimation strategy that permitted us to control for the time-invariant unobservable characteristics of graduates. The results show that finding a job using a university-based search method is associated with a reduced probability of over-education compared with responding to a job advertisement. Older

\footnotetext{
${ }^{19}$ Watts (1997) listed the functions of a university careers office as being guidance, information and placement, although he noted that an active placement function, such as a pre-filtering process that would allow employers to target the best graduates, is not typically offered due to resource limitations. Watts' report focused solely on careers offices in the UK; however, in our experience, these are also the primary functions of university careers offices in Australia.

${ }^{20}$ Graduates who had actively searched for work in the 12 months prior to the AGS were instructed to identify all of the methods they had used. This question did not specifically relate to the job they held at the time of the survey, nor did it ask whether this job search was ultimately successful.
} 
male graduates who found work through their contact networks were also less likely to be overeducated, although the same effect was not observed for young graduates of either gender or older females.

A recent survey of survey of graduate employers in Australia found that $28 \%$ would have recruited more graduates had more suitable candidates applied, which provides further evidence that inefficient job search may be a contributing factor to graduate over-education (GCA, 2012c). A more effective job search may be able to match graduates with these job vacancies. As university-based search methods are effective in terms of matching graduates with appropriate job vacancies, yet they are among the least used search methods, university administrators may be well advised to develop strategies to foster the widespread use of university career advice services among students and graduates, and to encourage employers to make use of this search channel. While it is unrealistic to suggest that over-education can be mitigated entirely by improving job-search practices, any reduction in over-education is likely to benefit graduates and the wider economy. Moreover, such a strategy could potentially be realised through the careers service infrastructure already within many higher education institutions.

In addition to job search methods, the determinants of over-education include age (which may include work experience) and field of study. The strong correlation between field of study estimates and graduate unemployment rates suggests that this effect is closely related to the demand for discipline-specific skills in the labour market. Graduates in part-time employment are more likely to be over-educated, which reflects the structure of the broader labour force, implying that overeducation will continue to be an issue in the graduate labour market as long as the supply of graduates from specific discipline areas exceeds the demand for their skills. It is likely that over-education will become more common in the immediate future, since the Australian Government's current studentdemand-driven system of funding university places does not explicitly consider the labour market demand for particular skills. Even under the previous regulated system of funding university places, ${ }^{21}$ historical graduate unemployment rates suggest that prospective university students are not always

\footnotetext{
${ }^{21}$ The current student-demand-driven system was introduced in January 2012.
} 
good judges of the future labour market demand for skills. ${ }^{22}$ As such, any effort to reduce overeducation should look to better align the supply of graduates with the labour market demand for skills by selectively limiting the former and, where appropriate, stimulating the latter.

While the BGS data have a number of key strengths, they do have an important weakness. As only one search method is associated with a particular job in the BGS data, our analysis cannot account for the concurrent use of multiple job search methods, nor other measures of search intensity. As noted earlier, our results relate only to graduates' main method of job attainment and not necessarily every method used as part of a broader job search strategy. This aside, the results are quite robust.

\section{References}

Addison, J.T., \& Portugal, P. (2002). Job search methods and outcomes. Oxford Economic Papers, 54 (3), 505-533.

Alba-Ramirez, A. (1993). Mismatch in the Spanish labor market: overeducation? Journal of Human Resources, 27 (2), 259-278.

Australian Bureau of Statistics (2006). Australian and New Zealand Standard Classification of Occupations, First Edition (Cat. No. 1220.0). Canberra, Author.

Australian Bureau of Statistics (2011). Forms of Employment (Cat. No. 6359.0). Canberra, Author.

Battu, H., Belfield, C.R. \& Sloane, P. (1999). Overeducation among graduates: a cohort view. Education Economics, 7 (1), 21-38.

Black, D.A., \& Smith, J.A. (2006). Estimating the returns to college quality with multiple proxies for quality. Journal of Labor Economics, 24 (3), 701-728.

Birch, E.R., Li, I., \& Miller, P.W. (2009). The influences of institution attended and field of study on graduates’ starting salaries. Australian Economic Review, 42 (1), 42-63.

Blau, D.M., \& Robins, P.K. (1990). Job search outcomes for the employed and unemployed. Journal of Political Economy, 98 (3), 637-655.

\footnotetext{
${ }^{22}$ See, for example, GCA (2012a).
} 
Blázquez, M., \& Mora, T. (2010). Over-education and job mobility: evidence from young recent university graduates in Catalonia. Revista de Economía Laboral, 7 (1), 64-84.

Cardoso, A.R. (2007). Jobs for young university graduates: is it worth having a degree? Economics Letters, 94 (2), 271-277.

Carroll, D., \& Tani, M. (2013). Over-education of recent higher education graduates: new Australian panel evidence. Economics of Education Review, 32, 207-218.

Chamberlain, G. (1980). Analysis of covariance with qualitative data. Review of Economic Studies, 47 (1), 225-238.

Coates, H., Tilbrook, C., Guthrie, B., \& Bryant, G. (2006). Enhancing the GCA National Surveys: An examination of critical factors leading to enhancements in the instrument, methodology and process. Canberra, Department of Education, Science and Training.

Department of Education, Employment and Workplace Relations (2008a). Staff 2007: Selected Higher Education Statistics. Canberra, Author.

Department of Education, Employment and Workplace Relations (2008b). Students 2007: Selected Higher Education Statistics. Canberra, Author.

Department of Education, Employment and Workplace Relations (2009). Students 2008: Selected Higher Education Statistics. Canberra, Author.

Department of Industry, Innovation, Science, Research and Tertiary Education (2012). Students 2011: Selected Higher Education Statistics. Canberra, Author.

Dolton, P., \& Silles, M. (2001). Over-education in the graduate labour market: some evidence from alumni data. Centre for the Economics of Education, London School of Economics and Political Science, Discussion Paper No. 9.

Dolton, P., \& Vignoles, A. (2000). The incidence and effects of overeducation in the U.K. graduate labour market. Economics of Education Review, 19 (2), 179-198.

Duncan, G.J., \& Hoffman, S.D. (1981). The incidence and wage effects of overeducation. Economics of Education Review, 1 (1), 75-86.

Franzen, A., \& Hangartner, D. (2006). Social networks and labour market outcomes: the nonmonetary benefits of social capital. European Sociological Review, 22 (4), 353-368. 
Frenette, M. (2004). The overqualified Canadian graduate: the role of the academic program in the incidence, persistence, and economic returns to overqualification. Economics of Education Review, 23 (1), 29-45.

Gottschalk, P., \& Hansen, M. (2003). Is the proportion of college workers in non-college jobs increasing? Journal of Labor Economics, 21 (2), 409-448.

Graduate Careers Australia (2012a). Graduate Destinations 2011. Melbourne, Author.

Graduate Careers Australia (2012b). Beyond Graduation 2011. Melbourne, Author.

Graduate Careers Australia (2012c). Graduate Outlook 2011. Melbourne, Author.

Grazier, S., O’Leary, N.C., \& Sloane, P.J. (2008). Graduate employment in the UK: an application of the Gottschalk-Hansen model. IZA, Discussion Paper No. 3618.

Gregg, P., \& Wadsworth, J. (1996). How effective are state employment agencies? Jobcentre use and job matching in Britain. Oxford Bulletin of Economics and Statistics, 58 (3), 443-468.

Groot, W., \& Maassen van den Brink, H. (2000). Overeducation in the labor market: a meta-analysis. Economics of Education Review, 19 (2), 149-158.

Halaby, C.N. (1994). Overeducation and skill mismatch. Sociology of Education, 67 (1), 47-59.

Hartog, J. (2000). Overeducation and earnings: where are we, where should we go. Economics of Education Review, 19 (2), 131-147.

Holzer, H.J. (1988). Search method use by unemployed youth. Journal of Labor Economics, 6 (1), 120.

Kler, P. (2005). Graduate overeducation in Australia: a comparison of the mean and objective methods. Education Economics, 13 (1), 47-72.

Krug, G., \& Rebien, M. (2011). Job search via social networks: an analysis of monetary and nonmonetary returns for low-skilled unemployed. IAB, Discussion Paper No. 201123.

Kucel, A. (2011). Literature survey of the incidence of over-education: a sociological approach. Revista Española de Investigaciones Sociologicas, 134, 125-142.

Kucel, A., \& Byrne, D. (2008). Are over-educated people insiders or outsiders? A case of job search methods and over-education in UK. ESRI, Working Paper No. 258. 
Linsley, I. (2005). Causes of overeducation in the Australian labour market. Australian Journal of Labour Economics, 8 (2), 121-143.

Mavromaras, K., McGuinness, S., O’Leary, N., Sloane, P., \& Wei, Z. (2010). Job mismatches and labour market outcomes: panel evidence on Australian university graduates. National Institute of Labour Studies, Flinders University, Working Paper No. 163.

McGuinness, S. (2006). Overeducation in the labour market. Journal of Economic Surveys, 20 (3), $387-418$.

McGuinness, S., \& Sloane, P.J. (2011). Labour market mismatch among UK graduates: an analysis using REFLEX data. Economics of Education Review, 30 (1), 130-145.

Metha, A., Felipe, J., Quising, P., \& Camingue, S. (2011). Overeducation in developing economies: how can we test for it, and what does it mean? Economics of Education Review, 30 (6), 13341347.

Mundlak, Y. (1978). On the pooling of time series and cross section data. Econometrica, 46 (1), 6985.

Norton, A. (2012). Mapping Australian Higher Education. Melbourne, Grattan Institute.

Osberg, L. (1993). Fishing in different pools: job search strategies and job-finding success in Canada in the early 1980s. Journal of Labor Economics, 11 (2), 348-386.

Queensland Tertiary Admissions Centre (2012). Semester 1 2012. Brisbane, Author.

Rumberger, R.W. (1987). The impact of surplus schooling on productivity and earnings. Journal of Human Resources, 22 (1), 24-50.

Spence, M. (1973). Job market signalling. Quarterly Journal of Economics, 87 (3), 355-374.

Tsai, Y. (2010). Returns to overeducation: a longitudinal analysis of the U.S. labor market. Economics of Education Review, 29 (4), 606-617.

Tsang, M.C., \& Levin, H.M. (1985). The economics of over-education. Economics of Education Review, 4 (2), 93-104.

Verhaest, D., \& Omey, E. (2010). The determinants of overeducation: different measures, different outcomes? International Journal of Manpower, 31 (6), 608-625. 
Watts, A.G. (1997). Strategic Directions for Careers Services in Higher Education. Sheffield and Cambridge, Association of Graduate Careers Advisory Services/CRAC.

Weber, A., \& Mahringer, H. (2006). Choice and success of job search methods. IZA, Discussion Paper No. 1939.

Williams, R. (2008). Ranking Australian universities: controlling for scope. Higher Education in Europe, 33 (2-3), 331-344.

Wooldridge, J.M. (2002). Econometric Analysis of Cross Section and Panel Data. Cambridge and London, The MIT Press. 


\section{Appendix A: Definition of variables}

The variables used in our analysis are defined as follows. Dummy variables have been coded such that $1=$ yes and $0=$ no. Sample means are presented in Table 1.

overed: Dummy variable to indicate over-education.

ageyr1: $\quad$ Age in years at the time of each survey wave.

ageyr2: $\quad$ Quadratic term for ageyr1.

major: Dummy variable to indicate major field of study; denoted with $a$ if sciences, $b$ if information technology, $c$ if engineering and related, $d$ if health, $e$ if education, $f$ if society and culture, $g$ if creative arts, base case being management and commerce.

unqual: $\quad$ University quality score (see Section 3 for description).

fywork: Dummy variable to indicate that a graduate was in paid employment during his or her final year of study.

ptwork: Dummy variable to indicate employment on a part-time or casual basis.

jbsch: $\quad$ Dummy variable to indicate job search method; denoted with $a$ if university-based method, $b$ if networking, $c$ if direct employer contact, $d$ if other job search method, base case being advertisements.

empst: $\quad$ Dummy variable to indicate employment location; denoted with $a$ if Victoria, $b$ if Queensland, $c$ if South Australia/Northern Territory, $d$ if Western Australia, $e$ if Tasmania, base case being New South Wales/Australian Capital Territory.

jbyear: Dummy variable to indicate year 2011.

m_ptwork: $\quad$ Mundlak time-average for ptwork.

m_jbsch: $\quad$ Mundlak time-average for jbsch.

m_empst: $\quad$ Mundlak time-average for empst. 
Table 1

Sample means

\begin{tabular}{|c|c|c|c|c|c|}
\hline \multirow[t]{2}{*}{ Variable } & \multirow[t]{2}{*}{ Name } & \multicolumn{2}{|c|}{ Traditional (aged < 25) } & \multicolumn{2}{|c|}{ Non-traditional (aged $\geq 25$ ) } \\
\hline & & Male & Female & Male & Female \\
\hline Over-educated & overed & 0.269 & 0.314 & 0.225 & 0.217 \\
\hline Age & ageyr1 & 23.779 & 23.611 & 34.842 & 37.268 \\
\hline Sciences & majora & 0.109 & 0.109 & 0.082 & 0.048 \\
\hline Information technology & majorb & 0.096 & 0.008 & 0.109 & 0.021 \\
\hline Engineering and related & majorc & 0.156 & 0.033 & 0.123 & 0.020 \\
\hline Health & majord & 0.082 & 0.204 & 0.128 & 0.243 \\
\hline Education & majore & 0.035 & 0.118 & 0.112 & 0.177 \\
\hline Society and culture & majorf & 0.184 & 0.240 & 0.197 & 0.300 \\
\hline Creative arts & majorg & 0.039 & 0.098 & 0.041 & 0.061 \\
\hline University quality & unqual & -0.438 & -0.421 & -0.167 & -0.058 \\
\hline Paid work in final year of study & fywork & 0.895 & 0.917 & 0.907 & 0.865 \\
\hline Working part time or casual & ptwork & 0.163 & 0.221 & 0.117 & 0.236 \\
\hline University-based method & jbscha & 0.230 & 0.180 & 0.138 & 0.118 \\
\hline Networking & jbschb & 0.250 & 0.230 & 0.247 & 0.237 \\
\hline Direct employer contact & jbschc & 0.142 & 0.150 & 0.175 & 0.167 \\
\hline Other job search method & jbschd & 0.126 & 0.143 & 0.167 & 0.196 \\
\hline Employed in Vic & empsta & 0.307 & 0.370 & 0.227 & 0.270 \\
\hline Employed in Qld & empstb & 0.200 & 0.175 & 0.197 & 0.209 \\
\hline Employed in SA/NT & empstc & 0.090 & 0.092 & 0.111 & 0.154 \\
\hline Employed in WA & empstd & 0.082 & 0.069 & 0.107 & 0.121 \\
\hline Employed in Tas & empste & 0.012 & 0.013 & 0.036 & 0.024 \\
\hline $\mathrm{n}$ & & 1,024 & 2,400 & 732 & 1,218 \\
\hline
\end{tabular}


Table 2

Random-effects probit coefficients and selected average marginal effects for the determinants of overeducation $^{\text {ab }}$

\begin{tabular}{|c|c|c|c|c|}
\hline \multirow[t]{2}{*}{ Variable } & \multicolumn{2}{|c|}{ Traditional (aged < 25) } & \multicolumn{2}{|c|}{ Non-traditional (aged $\geq 25$ ) } \\
\hline & Male & Female & Male & Female \\
\hline \multicolumn{5}{|l|}{ Probit coefficients } \\
\hline \multirow[t]{2}{*}{ Age } & -0.2305 & -0.1874 & $0.0618^{* *}$ & $-0.0572 * *$ \\
\hline & $(0.165)$ & $(0.116)$ & $(0.030)$ & $(0.024)$ \\
\hline \multirow[t]{2}{*}{ Age squared } & 0.0217 & 0.0048 & -0.0015 & 0.0010 \\
\hline & $(0.016)$ & $(0.011)$ & $(0.001)$ & $(0.001)$ \\
\hline \multirow[t]{2}{*}{ Sciences } & 0.0951 & -0.1953 & -0.0221 & 0.3932 \\
\hline & $(0.250)$ & $(0.199)$ & $(0.354)$ & $(0.392)$ \\
\hline \multirow[t]{2}{*}{ Information technology } & $-0.6064 * *$ & -0.7632 & -0.5770 & $0.9795^{*}$ \\
\hline & $(0.282)$ & $(0.648)$ & $(0.367)$ & $(0.526)$ \\
\hline \multirow[t]{2}{*}{ Engineering and related } & $-0.7348 * * *$ & $-0.6700^{*}$ & 0.0440 & -0.6609 \\
\hline & $(0.255)$ & $(0.347)$ & $(0.326)$ & $(0.644)$ \\
\hline \multirow[t]{2}{*}{ Health } & $-0.8244 * * *$ & $-1.1677 * * *$ & -0.0692 & $-0.8728 * * *$ \\
\hline & $(0.312)$ & $(0.189)$ & $(0.327)$ & $(0.291)$ \\
\hline \multirow[t]{2}{*}{ Education } & $-1.1127^{* *}$ & $-2.0839 * * *$ & -0.5691 & $-1.5217^{* * *}$ \\
\hline & $(0.479)$ & $(0.274)$ & $(0.346)$ & $(0.350)$ \\
\hline \multirow[t]{2}{*}{ Society and culture } & 0.3289 & 0.2481 & $0.6887 * *$ & 0.3218 \\
\hline & $(0.208)$ & $(0.158)$ & $(0.274)$ & $(0.249)$ \\
\hline \multirow[t]{2}{*}{ Creative arts } & -0.1348 & -0.1337 & $1.0840 * *$ & $0.6255^{*}$ \\
\hline & $(0.376)$ & $(0.200)$ & $(0.431)$ & $(0.361)$ \\
\hline \multirow[t]{2}{*}{ University quality } & $0.1655^{*}$ & 0.0376 & 0.1787 & 0.1001 \\
\hline & $(0.089)$ & $(0.069)$ & $(0.115)$ & $(0.102)$ \\
\hline \multirow[t]{2}{*}{ Paid work in final year of study } & -0.0030 & 0.3173 & 0.3044 & $0.5821^{* *}$ \\
\hline & $(0.255)$ & $(0.219)$ & $(0.325)$ & $(0.283)$ \\
\hline \multirow[t]{2}{*}{ Working part time or casual } & $1.4786^{* * *}$ & $1.4328 * * *$ & $1.0971^{* * *}$ & $0.9252^{* * *}$ \\
\hline & $(0.195)$ & $(0.129)$ & $(0.244)$ & $(0.174)$ \\
\hline \multirow[t]{2}{*}{ University-based method } & $-0.8823^{* * *}$ & $-0.6932 * * *$ & $-0.6795^{* *}$ & $-0.9235^{* * *}$ \\
\hline & $(0.211)$ & $(0.150)$ & $(0.283)$ & $(0.270)$ \\
\hline \multirow[t]{2}{*}{ Networking } & -0.0192 & $0.2523 * *$ & -0.2501 & -0.0906 \\
\hline & $(0.176)$ & $(0.126)$ & $(0.219)$ & $(0.180)$ \\
\hline \multirow[t]{2}{*}{ Direct employer contact } & 0.0632 & $0.2394 *$ & $-0.5687^{* *}$ & -0.2351 \\
\hline & $(0.199)$ & $(0.145)$ & $(0.244)$ & $(0.208)$ \\
\hline \multirow[t]{2}{*}{ Other job search method } & -0.2489 & -0.0753 & -0.2067 & -0.1884 \\
\hline & $(0.215)$ & $(0.150)$ & $(0.240)$ & $(0.204)$ \\
\hline \multicolumn{5}{|l|}{ Controls } \\
\hline Employment location & Yes & Yes & Yes & Yes \\
\hline Job year & Yes & Yes & Yes & Yes \\
\hline \multicolumn{5}{|l|}{ Selected average marginal effects } \\
\hline University-based method & $-0.1797 * * *$ & $-0.1359 * * *$ & $-0.1275^{* *}$ & $-0.1541^{* * *}$ \\
\hline Networking & -0.0039 & $0.0495 * *$ & -0.0469 & -0.0151 \\
\hline Direct employer contact & 0.0129 & $0.0470 *$ & $-0.1067 * *$ & -0.0392 \\
\hline Other job search method & -0.0507 & -0.0148 & -0.0388 & -0.0314 \\
\hline $\mathrm{n}$ & 1,024 & 2,400 & 732 & 1,218 \\
\hline Log likelihood & -465.73 & -1088.08 & -317.46 & -501.48 \\
\hline Prob > F & 0.0000 & 0.0000 & 0.0000 & 0.0000 \\
\hline
\end{tabular}

${ }^{a}$ Standard errors are in parentheses.

${ }^{\mathrm{b}}$ The dependent variable is a dummy to indicate over-education.

* significant at $10 \%$;** significant at $5 \%$; *** significant at $1 \%$ 
Table 3

Mundlak-Chamberlain random-effects probit coefficients and selected average marginal effects for the determinants of over-education ${ }^{\text {ab }}$

\begin{tabular}{|c|c|c|c|c|}
\hline \multirow[t]{2}{*}{ Variable } & \multicolumn{2}{|c|}{ Traditional (aged < 25) } & \multicolumn{2}{|c|}{ Non-traditional (aged $\geq 25$ ) } \\
\hline & Male & Female & Male & Female \\
\hline \multicolumn{5}{|l|}{ Probit coefficients } \\
\hline Working part time or casual & $\begin{array}{r}1.3433^{* * * *} \\
(0.254)\end{array}$ & $\begin{array}{r}1.1864^{* * *} \\
(0.161)\end{array}$ & $\begin{array}{r}0.9933^{* * *} \\
(0.360)\end{array}$ & $\begin{array}{r}0.8090^{* * *} \\
(0.256)\end{array}$ \\
\hline University-based method & $\begin{array}{r}-0.5568^{*} \\
(0.313)\end{array}$ & $\begin{array}{r}-0.4480^{* *} \\
(0.205)\end{array}$ & $\begin{array}{r}-0.7146 * \\
(0.422)\end{array}$ & $\begin{array}{r}-0.7883^{* *} \\
(0.359)\end{array}$ \\
\hline Networking & $\begin{array}{l}0.2855 \\
(0.262)\end{array}$ & $\begin{array}{l}0.1449 \\
(0.171)\end{array}$ & $\begin{array}{l}-0.5207 \\
(0.333)\end{array}$ & $\begin{array}{r}-0.0237 \\
(0.243)\end{array}$ \\
\hline Direct employer contact & $\begin{array}{l}0.3656 \\
(0.272)\end{array}$ & $\begin{array}{l}0.0414 \\
(0.192)\end{array}$ & $\begin{array}{r}-0.7848^{* *} \\
(0.324)\end{array}$ & $\begin{array}{l}0.0546 \\
(0.285)\end{array}$ \\
\hline Other job search method & $\begin{array}{r}-0.1625 \\
(0.292)\end{array}$ & $\begin{array}{l}-0.1749 \\
(0.196)\end{array}$ & $\begin{array}{l}-0.1369 \\
(0.347)\end{array}$ & $\begin{array}{c}0.1212 \\
(0.281)\end{array}$ \\
\hline \multicolumn{5}{|l|}{ Controls } \\
\hline Age/age squared & Yes & Yes & Yes & Yes \\
\hline Major field of study & Yes & Yes & Yes & Yes \\
\hline University rating & Yes & Yes & Yes & Yes \\
\hline Paid work in final year of study & Yes & Yes & Yes & Yes \\
\hline Employment location & Yes & Yes & Yes & Yes \\
\hline Job year & Yes & Yes & Yes & Yes \\
\hline Mundlak time-averages & Yes & Yes & Yes & Yes \\
\hline \multicolumn{5}{|l|}{ Selected average marginal effects } \\
\hline University-based method & $-0.0630 *$ & $-0.0328 * *$ & $-0.0789 *$ & $-0.0790 * *$ \\
\hline Networking & 0.0278 & 0.0088 & -0.0561 & -0.0022 \\
\hline Direct employer contact & 0.0346 & 0.0026 & $-0.0872^{* *}$ & 0.0051 \\
\hline Other job search method & -0.0176 & -0.0119 & -0.0136 & 0.0112 \\
\hline $\mathrm{n}$ & 1,024 & 2,400 & 732 & 1,218 \\
\hline Log likelihood & -461.19 & -1073.98 & -313.45 & -495.53 \\
\hline Prob $>$ F & 0.0000 & 0.0000 & 0.0022 & 0.0000 \\
\hline
\end{tabular}

${ }^{a}$ Standard errors are in parentheses.

${ }^{\mathrm{b}}$ The dependent variable is a dummy to indicate over-education.

* significant at $10 \%$; ** significant at $5 \%$; *** significant at $1 \%$ 
Table 4

Distribution of occupational skill levels by job search channel ${ }^{\mathrm{a}}$

\begin{tabular}{lrrrr}
\hline Job search method & Mean & & St. dev. & $\mathrm{n}$ \\
\hline Advertisements & 1.29 & 0.81 & 912 \\
University-based method & 1.69 & 1.24 & 1,515 \\
Networking & 1.83 & 1.34 & 1,277 \\
Direct employer contact & 1.77 & 1.33 & 836 \\
Other job search method & 1.47 & 1.03 & 834 \\
\hline Total & 1.63 & 1.20 & 5,374 \\
\hline
\end{tabular}

${ }^{\mathrm{a}}$ Occupational skill levels range from 1 (highest) to 5 (lowest). 